Oecologia, 1992, v.89, n.2, pp.153-160

ISSN: 0029-8549 (Print) 1432-1939 (Online)

DOI: $10.1007 /$ BF00317212

The original publication is available at www.springerlink.com

(C) 1992 Springer-Verlag

\title{
Bluegill growth as modified by plant density: an exploration of underlying mechanisms
}

Jacqueline F. Savino and Elizabeth A. Marschall

Ohio Cooperative Fish and Wildlife Unit, Department of Zoology, The Ohio State University

Roy A. Stein

Department of Zoology, The Ohio State University

\section{Summary.}

Bluegill (Lepomis macrochira) growth varies inconsistently with plant density. In laboratory and field experiments, we explored mechanisms underlying bluegill growth as a function of plant and invertebrate density. In the laboratory, bluegills captured more chironomids (Chironomus riparius) than damselflies (Enallagma spp. and Ischnura spp.), but energy intake per time spent searching did not differ between damselfly and chironomid treatments. From laboratory data, we described prey encounter rates as functions of plant and invertebrate density. In Clark Lake, Ohio, we created 0.05 -ha mesocosms of inshore vegetation to generate macrophyte densities of 125 , 270, and 385 stems $/ \mathrm{m}^{2}$ of Potamogeton and Ceratophyllum and added 46- $\mathrm{mm}$ bluegill $\left(1 / \mathrm{m}^{2}\right)$. In these mesocosms, invertebrate density increased as a function of macrophyte density. Combining this function with encounter rate functions derived from laboratory data, we predicted that bluegill growth should peak at a high macrophyte density, greater than $1000 \mathrm{stems} / \mathrm{m}^{2}$, even though growth should change only slightly beyond $100 \mathrm{stems} / \mathrm{m}^{2}$. Consistent with our predictions, bluegills did not grow differentially, nor did their use of different prey taxa differ, across macrophyte densities in the field. Bluegills preferred chironomid pupae, which were relatively few in numbers but vulnerable to predation, whereas more cryptic, chironomid larvae, which were associated with vegetation but were relatively abundant, were eaten as encountered. Bluegills avoided physid snails, which were abundant. Contrary to previous work, vegetation did not influence growth or diet of bluegill beyond relatively low densities owing to the interaction between capture probabilities and macroinvertebrate densities.

Productive ponds in north temperate regions usually contain both high plant densities and dense populations of slow-growing fish (Regier 1962; Judd and Taub 1973; Barnett and Schneider 1974). Although high plant densities are usually indicative of high invertebrate densities (Gerking 1957; Gerrish and Bristow 1979; Wiley et al. 1984), feeding efficiency of predatory fish declines as plant density increases (Glass 1971; Savino and Stein 1982; Cook and Streams 1984; Gotceitas and Colgan 1989). Because both prey density and difficulty of capturing prey are opposing functions of plant density, we expect growth rates of predators to be also a function of plant density. Whether maximum growth rates of predators occur at low, high, or some intermediate plant density is determined by the specific nature of these functions.

Testing this relationship in the field has produced a variety of results. Bluegill (Lepomis macrochira), a common fish whose slow-growing populations are often associated with dense vegetation (Murnyak et al. 1984), can grow optimally at an intermediate plant density (Crowder and Cooper 1982). For example, reducing plant density with a herbicide can increase bluegill growth (Cope et al. 1970). Though Wiley et al. (1984) documented that bluegill production was a simple increasing function of plant abundance, Bennett (1948) revealed that a sudden plant dieoff produced no change in bluegill growth. Clearly, the relationship between plant density and predator growth, even within the same predator species, is not simple. 
Specific aspects of this relationship have been studied separately. Some studies have concentrated on behavior of predators in different plant densities in the laboratory (largemouth bass, Micropterus salmoides: Glass 1971; Savino and Stein 1982; Anderson 1984; Gotceitas and Colgan 1989); others have quantified diet choice (bluegills: Crowder and Cooper 1982; Werner et al. 1983a; Gilinsky 1984; Schramm and Jirka 1989) or growth (bluegills: Crowder and Cooper 1982) of predators in vegetation in the field. However, a comprehensive study evaluating the importance of each factor on the growth of predators, such as bluegills, is lacking.

Here, we use laboratory and field experiments to explore this relationship for bluegills. In laboratory experiments, we quantified capture rates as a function of plant density at a constant prey density and as a function of prey density at a constant plant density. In field experiments, we quantified invertebrate density as a function of plant density. From these relationship, we predicted the plant density at which bluegills should have grown most rapidly and tested this prediction in the field in various macrophyte densities. We furthermore examined the mechanisms that ultimately influence bluegill growth by 1) comparing responses by bluegills to two types of prey in laboratory experiments to assist us in translating laboratory results to field conditions and 2) comparing taxonomic composition of available prey and diets of bluegills among plant densities in the field.

\section{Materials and methods}

Laboratory: bluegill capture rates

To determine how bluegill capture rate varied in different plant densities, we examined the effects of prey and plant density on foraging behavior of bluegills in the laboratory. Experiments were conducted in 50-L glass aquaria (filled to $40 \mathrm{~L}$ ) with buoyant polypropylene rope (3-mm diameter, green) attached to a plexiglass bottom to simulate aquatic macrophytes. Water temperature was about $25^{\circ} \mathrm{C}$. Held in separate tanks between experiments, bluegill were satiated on chironomid larvae (Chironomus riparius) $24 \mathrm{~h}$ before testing.

To quantify how plant density influenced capture rate, we observed bluegills $(50-60 \mathrm{~mm}$ total length) foraging in each of four stem densities $\left(50,250,1,000\right.$, and 2,000 rope stems $\left./ \mathrm{m}^{2}\right)$. In previous experiments with largemouth bass foraging for bluegill in plant densities ranging from 0 to $1000 \mathrm{stems} / \mathrm{m}^{2}$, important changes in behavior and capture success occurred over the range of 50 to $1000 \mathrm{stems} / \mathrm{m}^{2}$ (Savino and Stein 1982). Because we were looking at smaller scale interactions, i.e., bluegill as predators on invertebrate prey, we added another higher plant density treatment. Because stems of real plants, such as Potamogeton spp., are structurally more complex than rope stems, we converted rope-stem densities to densities of $P$. natans that would provide an equivalent amount of cover by the relation: vegetation density $=(0.236)$ (rope stem density $)^{(1.094)}$ based on data in Savino and Stein (1982). Because P. natans is structurally similar to $P$. nodosus at our field site, we assumed this relation held for $P$. nodosus. Thus, vegetation densities for trials with bluegills were 17, 99, 452, and 964 plants $/ \mathrm{m}^{2}$. Throughout this paper, we refer to rope-stem densities by their vegetation density equivalents.

For prey, frozen chironomid larvae (Chironomus riparius) were thawed and attached to stems with silicon rubber at 255 individuals $/ \mathrm{m}^{2}$. We observed six to seven individual bluegills in one to three foraging bouts each in each of four vegetation densities. During each foraging bout, we recorded the time of each prey capture and time spent searching for and handling prey. To test for effects of vegetation density on capture rate during the first $5 \mathrm{~min}$ of foraging, we used ANOVA (blocking by individual bluegill).

To determine whether different prey densities affected capture rates by bluegills, we 
quantified foraging behavior in each of four prey densities $(30,60,120$, and 255 chironomid larvae $/ \mathrm{m}^{2}$ ) spanning a range of densities observed in littoral vegetation. These experiments were done at one vegetation density $\left(964\right.$ plants $\left./ \mathrm{m}^{2}\right)$, using experimental protocol described above. If vegetation density does modify foraging success of bluegill, it should occur at this high density. We used three to seven fish, in one to four foraging experiments each, at each prey density. Analyses were done on means for each fish in each prey density treatment.

Because we used immobile prey distributed randomly on stems in the above experiments, we needed to determine whether natural prey behavior would modify foraging behavior and success by bluegills. We compared bluegills foraging in experiments using immobile chironomids as prey to experiments using live damselfly nymphs (Enallagma spp. and Ischnura spp.) at 99 plants $/ \mathrm{m}^{2}$ and $255 \mathrm{prey} / \mathrm{m}^{2}$. Prey captures and time spent searching for prey were monitored during 15-min tests with each prey type. We used these data to calculate energy intake per time spent searching for each prey type with dry mass $(\mathrm{g})$ to caloric content conversions $(\mathrm{J})$ from Cummins and Wuycheck (1971). The analysis was based on a total of 26 foraging bouts (9 fish) for damselfly prey and 10 foraging bouts ( 6 fish) for chironomid prey. Where necessary, we $\log$ transformed data from all tests to equalize variances before statistical analysis. In these analyses, we treated fish as blocks to separate the effects of individual fish from the effect of prey type.

\section{Field: bluegill diet and growth}

To determine how macrophyte density influenced prey abundance, diet, and growth of bluegill, we manipulated plant densities in Clark Lake, Ohio, and monitored diet and growth of bluegills at each plant density through $31 \mathrm{~d}$. We separated three adjacent sections $(0.05$-ha, $33 \times$ $15 \mathrm{~m}, 0.5 \mathrm{~m}$ mean depth) from the main body of Clark Lake along the littoral zone with nets (5$\mathrm{mm}$ mesh) that were supported above the water surface by stakes and buried into the mud substrate with lead lines and rocks. We removed emergent vegetation from each section manually and allowed submerged vegetation to grow naturally in the high plant density. Low and medium submerged vegetation sites were maintained at desired plant densities with drag lines. Water temperatures were $20-25^{\circ} \mathrm{C}$; Secchi disc readings remained about $0.5 \mathrm{~m}$.

Resident fish were cleared from the area with rotenone $(4 \mathrm{mg} / \mathrm{L})$ after nets were installed before plant growth in spring. We again applied rotenone 4 days before experiments began. Some fishes, such as bullheads (Ictalurus spp.) and sunfishes (Lepomis spp.) migrated into sections between applications of rotenone. Presumably, these fishes followed the substrate/water interface and located any sections of netting lifted out of the substrate. Originally, four sections were prepared for this study but young-of-year sunfishes (small enough to move through the mesh) primarily moved into the section nearest the main body of the lake and on the windward side; hence, that section (containing vegetation similar to the low plant density section) was eliminated from the study (other than to provide samples for the relationship between vegetation and invertebrates) and acted as a buffer from the lake for the other sections. Unlike large fishes with extensive home ranges (Fish and Savitz 1983), we expect that small bluegills, having sufficient area to forage, should remain in a more restricted area. Even if some bluegills migrated through sections during the study, diets are likely to reflect foraging in that section. Foods commonly eaten by bluegills are about 80\% digested by $15 \mathrm{~h}$ (Windell 1967).

We used bluegills from Hebron fish farm, Hebron, Ohio. Two samples of bluegills (50 per sample) were counted and weighed (mean $=1.1 \mathrm{~g}$ per bluegill). Based on this average weight, we released the calculated mass for 500 bluegills in each section $\left(1 \mathrm{blue}\right.$-gill $\left./ \mathrm{m}^{2}\right)$. Total lengths 
of the bluegills in the two samples averaged $46.5 \mathrm{~mm}$ (46-47 mm, 95\% confidence interval). We sampled bluegills about once per week with $30-\mathrm{m}$ bag seines, moving slowly through a section to prevent plant loss. Weekly assessments of vegetation (described below) showed no impacts of seining on plant density. All sampled bluegills were measured (mm total length) and food habits were documented by subsampling 11-15 individuals per treatment on each sampling date and placing these samples on ice. Remaining bluegills were returned to their section. Later that day, we transferred iced stomach samples to $70 \%$ ethanol.

To quantify prey and vegetation density, we sampled plants and associated invertebrates from each section on day 0 and each fish-sampling date $(n=4$ samples/date). All samples collected during the study (including those on day 0 and from the buffer section) were used to generate a relationship between vegetation density and invertebrate density. To portray vegetation and invertebrate densities within a treatment during the bluegill feeding study, medians and $95 \%$ confidence intervals were calculated using only samples on the fish-sampling dates. The sampler consisted of two $0.1-\mathrm{m}^{2}$ rings, with $1-\mathrm{mm}$ mesh netting between the rings. Placed over a plant stand, one end of the sampler was lowered to the substrate. Plants were gathered by hand within the sampler at the substrate surface, then plants and their associated invertebrates were lifted out of the water. Some of the more mobile invertebrates (such as hemipterans) may have been undersampled with this method, but Schramm and Jirka (1989) found that most invertebrates remained with the plants even during this type of disturbance. Plants and invertebrates were placed in plastic bags and held on ice. Plant samples were refrigerated at $8^{\circ} \mathrm{C}(<1 \mathrm{wk})$ until invertebrates were separated from plants. Invertebrates were preserved in $70 \%$ ethanol until identified and counted. Plants were identified and counted after invertebrates were removed.

We used Freidman's rank sum to compare change in invertebrate taxa with time within each plant density section (Hollander and Wolfe 1973). We compared the relative importance of invertebrate taxa among plant density sections with Spearman rank correlations (Fritz 1974). Preferences for each prey item were determined by Johnson's preference test (1980). As a nonparametric test, this test ranks abundance and use by predators, then uses the difference between ranks for the statistic. This test provides comparable results whether or not a questionable diet item is included in the analysis. Medians and 95\% confidence intervals were calculated using Walsh averages (Hollander and Wolfe 1973).

\section{Results}

Laboratory: bluegill capture rates

Bluegill capture rate declined with increasing vegetation density in the first 5 min of a foraging bout (ANOVA, $P=0.002$, $\mathrm{df}=3,15$; Fig. 1). Capture rates also differed among individual fish $(P=0.004, \mathrm{df}=6,15)$.

We calculated mean time to capture an individual prey at each vegetation density for each fish (using methods from Marschall et al. 1989) and used these data to describe mean time to capture as a function of vegetation density. We chose to represent mean time to capture a particular prey $(\lambda)$ as an exponential function of vegetation density $(v)$ such that

$$
\lambda(v)=\mathrm{a} \mathrm{e}^{\mathrm{bv}} .
$$

We simply assumed capture time at a constant prey density to be a positive, monotonically increasing function of $\mathrm{v}$ with a positive value at $\mathrm{v}=0$. From our experiments, we estimated $\mathrm{a}=$ 


\section{7 and $b=0.0005$.}

At a constant vegetation density, bluegills had higher capture rates in high prey density treatments than in low (Fig. 2). One fish tested in the highest prey density (Fish I, $255 \mathrm{prey} / \mathrm{m}^{2}$ ) captured prey at a significantly lower rate than all other fish in all other treatments (Fig. 2); thus, we omitted data for this fish from subsequent analyses. Number of prey captured in the first $0.5 \mathrm{~min}$ of search was an increasing function of prey density $(P=0.015)$ that reached a maximum at the two highest prey densities of 120 and $255 \mathrm{prey} / \mathrm{m}^{2}(P=0.017)$ in these experiments.

In laboratory experiments, we compared bluegill foraging success between small, immobile prey (chironomid larvae) and large, mobile prey (damselfly nymphs). By moving around stems, Damselflynymphs actively avoided bluegill. Bluegills capture more prey (ANOVA, $P<0.0001$ ) and spent less search time per prey capture in chironomid than damselfly treatments (ANOVA, $P$ $=0.003$, Table 1$)$. However, a damselfly nymph contains much more energy than a chironomid larva (58 J/nymph as compared to $15 \mathrm{~J} /$ larva). Combining these three patterns, we found mean energy intake per search time did not differ between these prey types (ANOVA, $P=0.63$, Table 1 ), but that variance in energy intake per search time was greater for damselfly nymphs than chironomid larvae $(P<0.10$, Bartlett's test for homogeneity of variance). We saw no significant effect of individual fish in any of these responses (ANOVA, $P=0.25-0.38$ ).

Because fish ate more prey in chironomid treatments than damselfly treatments, search time per prey may have been influenced by lower prey densities near the end of chironomid experiments. We compared average search time per prey over the first seven prey captures $(20 \%$ of original prey) with search time per prey over the entire 15-min foraging bout and found no difference ( $t$-test, $P>0.5$ ). Thus, we conclude that the similarities in energy intake rate between prey types is real, and not an artifact of declining prey densities in one treatment.

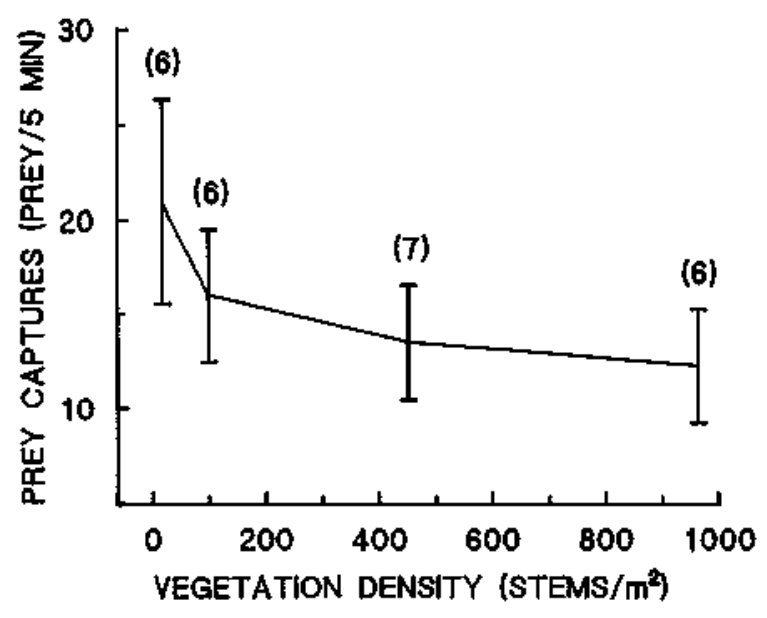

Fig. 1. Number of chironomid prey (255 individuals $/ \mathrm{m}^{2}$ ) captured by $50-60 \mathrm{~mm}$ bluegills in laboratory experiments at four vegetation densities. Rope-stem densities were converted to Potamogeton natans densities that would have provided an equivalent amount of cover (as per Savino and Stein 1982). Means and 95\% confidence intervals were calculated from the mean number captured per fish (based on one to three foraging experiments for each of six to seven fish at each vegetation density). Number of fish used at each density are given in parentheses 


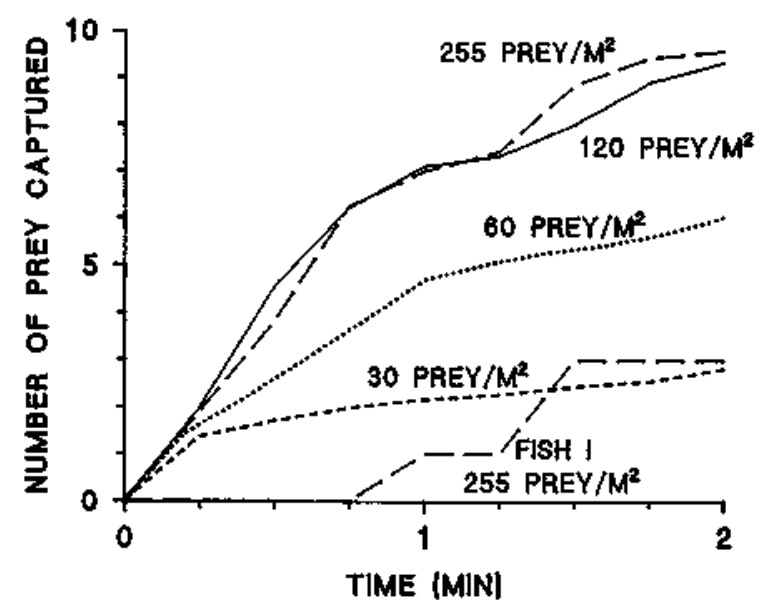

Fig. 2. Number of chironomid prey captured by $50-60 \mathrm{~mm}$ bluegill through time in each of four prey-density treatments in laboratory experiments with 964 plants $/ \mathrm{m}^{2}$. Lines connect means at $15-\mathrm{s}$ intervals of all fish tested at each prey density. Means were calculated from mean number captured per fish (based on one to four foraging experiments, for each of three to seven fish at each prey density). Data for fish-I were plotted separately (see text)

Table 1. Comparison of bluegill foraging success for two prey types in 15-min laboratory experiments with 255 prey $/ \mathrm{m}^{2}$ at a vegetation density of $954 \mathrm{stems} / \mathrm{m}^{2}$. Values are means (standard deviations) and P-values from comparisons using ANOVA $(\mathrm{df}=1,4)$. Analyses of number of prey captured and energy intake rate were made with $\log$ transformed data to equalize variances

\begin{tabular}{|c|c|c|c|}
\hline Parameler & $\begin{array}{l}\text { Chironomid } \\
\text { larvae }\end{array}$ & $\begin{array}{l}\text { Damselfly } \\
\text { nymphs }\end{array}$ & $P$ \\
\hline Number eaptured & $26.6 \quad(7.2)$ & $3.0 \quad(1.0)$ & 0.0001 \\
\hline $\begin{array}{l}\text { Search time } \\
\text { per. prey (min) }\end{array}$ & $0.2 \quad(0.04)$ & $1.3 \quad(0.66)$ & 0.003 \\
\hline $\begin{array}{l}\text { Energy intake } \\
\text { per search } \\
\text { time }(\mathrm{J} / \mathrm{min})\end{array}$ & $78.1(18.4)$ & $77.8(52.2)$ & 0.63 \\
\hline
\end{tabular}

Field: bluegill diet and growth

Invertebrate density increased with vegetation density (Fig. 3). We assumed invertebrate density $\mathrm{n}$ (number $/ \mathrm{m}^{2}$ ) to be a positive, monotonically increasing function of vegetation density (v; plant stems $/ \mathrm{m}^{2}$ ), equalling 0 at $\mathrm{v}=0$ and approaching an asymptotic value as $\mathrm{v}$ gets very large such that

$$
\mathrm{n}(\mathrm{v})=58.2 \mathrm{v}^{0.6135}
$$

We expected an asymptote because at some high plant density, invertebrate density reaches a volume or space constraint.

Plant densities differed among sections, but proportions of each plant species remained constant over the course of the study. Plants grew to the water surface and plant lengths were similar among sections. Blocking by date, plant density increased significantly from low to high plant density treatments (Ordered alternative test based on Friedman rank sums, $P=0.01$ ). Low 
plant density was $125 / \mathrm{m}^{2}(75-170,95 \%$ confidence interval, $\mathrm{n}=16$ samples $)$, medium plant density was $270 / \mathrm{m}^{2}(220-345, \mathrm{n}=16)$, and high plant density was $385 / \mathrm{m}^{2}(315-480, \mathrm{n}=15)$. Plant density did not change with sampling date (Freidman test, $P=0.33$ ). $P$. nodosus, a floating leaf species, was dominant in all treatments - $64 \%$ of total in low, $81 \%$ in medium, and $78 \%$ in high. Ceratophyllum demersum, with dense, whorled leaves, was next in abundance - $36 \%$ of total in low, $19 \%$ in medium, and $22 \%$ in high. Other species, such as Najas spp., comprised < $2 \%$ of the samples.

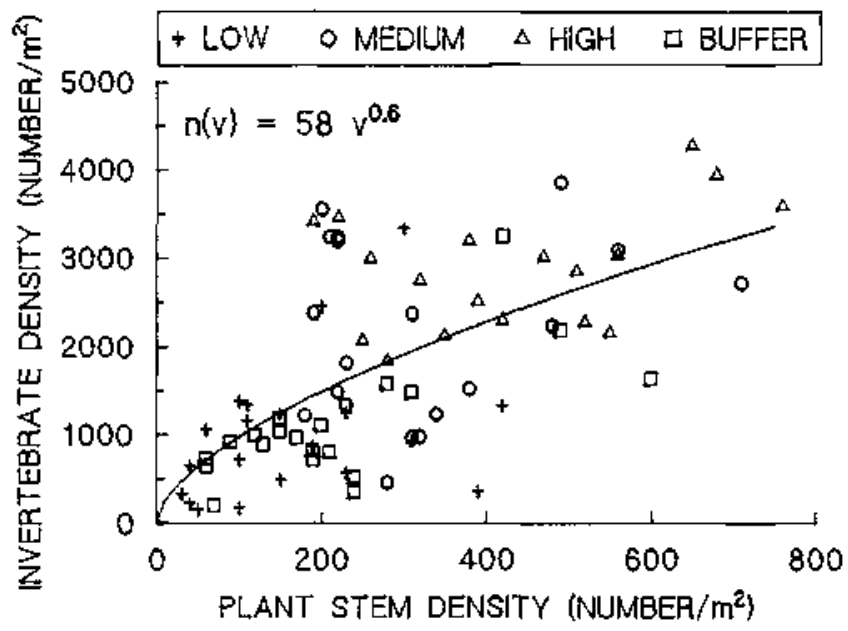

Fig. 3. Invertebrate and plant stem density in each section in Clark Lake, Ohio, during a 4-wk study. Plants and invertebrates were collected simultaneously in a sampler $\left(0.1 \mathrm{~m}^{2}\right.$ area $)$ in each section

Invertebrate density did not change with date within each plant density section (Table 2; Freidman's rank for 4 dates and 11 taxa, $P>0.05$ ). Thus, data from all sampling dates were used within a treatment for analysis. The invertebrate density within the $0.1 \mathrm{~m}^{2}$ sampler was 95 individuals/sampler (64-137, confidence interval, $\mathrm{n}=16)$ in low plant density, 223 (159-310, $\mathrm{n}$ $=15)$ in medium plant density, and $270(229-311, \mathrm{n}=16)$ in high plant density. The relative order of importance of each taxon with plant density treatment was quite similar - Spearman's rank correlation, using all 4 dates for each of the 11 taxa $\left(r_{s}, n=44, P<0.001\right)$ for Low-Medium $=0.82$, Low-High $=0.85$, and Medium-High $=0.87$. Gastropods (primarily Physidae) contributed to the largest category of invertebrates in each treatment, followed by dipterans (mainly Chironominae in Chironomidae). Homopterans (aphids), odonates (damselflies and dragonflies), and ephemeropterans (primarily Baetidae) followed in numerical dominance. Homopterans are unusual in aquatic samples but were found consistently on the water surface and floating leaves even $30 \mathrm{~m}$ from shore. Other invertebrates were each $<5 \%$ of total.

Invertebrate biomass eaten was not quantified. However, most diet items, and especially insects, were relatively similar in size. Snails eaten, though small $(<10 \mathrm{~mm})$, may have contributed somewhat more to diet biomass than chironomids; they may have been especially important to bluegills in high plant density on the last two sampling dates (Table 3). Cladocerans were small relative to other taxa; they were the diet item that differed most in terms of biomass.

Bluegill diet did not change with date within each plant density (Table 3; Freidman's rank for 4 dates and 10 taxa, $\mathrm{P}>0.05$ ). The relative importance of each taxon eaten in each plant 
density also was quite similar - Spearman's rank correlation, using all four dates for each of the 10 taxa $\left(\mathrm{r}_{\mathrm{s}}, n=40, \mathrm{P}<0.001\right)$, for Low-Medium $=0.61$, Low-High $=0.52$, and Medium-High $=0.71$. Bluegill in low plant density primarily consumed chironomid larvae and pupae. Bluegill in medium or high plant densities ate chironomid larvae and cladocerans. Physidae and Baetidae were consumed in small amounts in all plant densities. Other invertebrates eaten $(<15 \%$ of diet) included Leptoceridae, Corixidae, Ceratopogonidae, Coenagrionidae, and Homoptera.

Table 2. Average density (median, $n=4$ samples) of major invertebrate taxa (in order of relative abundance) collected in a sampler $\left(0.1 \mathrm{~m}^{2}\right)$ in each plant density treatment and sampling date in Clark Lake, Ohio. Larval (1) and adult (a) insect forms noted

\begin{tabular}{|c|c|c|c|c|c|c|c|c|c|c|c|c|}
\hline \multirow{4}{*}{$\begin{array}{l}\text { Invertebrate } \\
\text { taxon }\end{array}$} & \multicolumn{12}{|c|}{ Plant density treatment } \\
\hline & \multicolumn{4}{|c|}{ Low } & \multicolumn{4}{|c|}{ Medium } & \multicolumn{4}{|c|}{ High } \\
\hline & \multicolumn{4}{|c|}{$\overline{\text { Day }}$} & \multicolumn{4}{|c|}{ Day } & \multicolumn{4}{|l|}{ Day } \\
\hline & $\overline{10}$ & 17 & 25 & 31 & 10 & 17 & 25 & 31 & 10 & 172 & 25 & 31 \\
\hline Gastropoda & 32 & 52 & 86 & 31 & 40 & 108 & 215 & 56 & 66 & 99 ? & 90 & 90 \\
\hline Diptera (1) & 36 & 20 & 20 & 10 & 40 & 44 & 41 & 36 & 114 & 69 & 66 & 47 \\
\hline Homoptera (a) & 1 & 1 & 5 & 8 & 19 & 16 & 12 & 47 & 21 & 353 & 35 & 32 \\
\hline Odonata (1) & 5 & 8 & 8 & 3 & 12 & 27 & 16 & 28 & 10 & 343 & 31 & 39 \\
\hline Ephemeroptera (1) & 5 & 6 & 8 & 0 & 4 & 5 & 13 & 1 & & 13 & 16 & 4 \\
\hline Lepidoptera (1) & 1 & 2 & 1 & 1 & 9 & 4 & 1 & 3 & & 15 & 5 & 7 \\
\hline Coleoptera $(1$, a) & 2 & 2 & 4 & 1 & 4 & 10 & 2 & 2 & 3 & 4 & 6 & . \\
\hline Hirudinea & 1 & 0 & 5 & 0 & 6 & 4 & 1 & 4 & 2 & 2 & 9 & 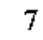 \\
\hline Hemiptera (a) & 0 & 2 & 0 & 1 & 1 & 2 & 1 & 1 & 4 & 2 & 4 & 3 \\
\hline Hymenoptera (1) & 0 & 0 & 0 & 0 & 0 & 0 & 1 & 1 & 2 & 2 & 0 & 0 \\
\hline Other & 0 & 0 & 1 & 0 & 0 & 3 & 6 & 0 & 1 & 2 & 6 & 1 \\
\hline
\end{tabular}

Because the relative abundance and use of invertebrates by bluegills did not change with plant ensity or time, we used the median for each taxon on each date and in each plant stem density treatment $(n=12$ observations of 9 taxa) to determine bluegill preference. Taxon preferences (values in parentheses, in order of most preferred to least preferred) which did not differ share the same superscript (Johnson's $t$ test; Johnson 1980):

Chironomid pupae $^{\mathrm{a}}(-3.2)$ Corixidae $^{\mathrm{ab}}(-1.9)$ Leptoceridae $^{\mathrm{ab}}(-1.7)$ Baetidae $^{\mathrm{ab}}(-1.1)$ Chironomid

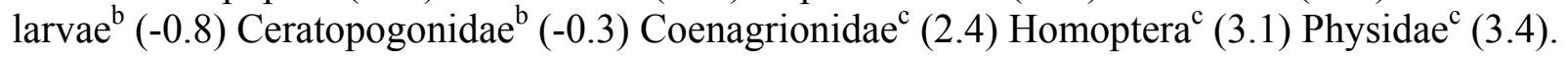

Bluegills most preferred chironomid pupae and least preferred physids. Even though chironomid larvae were consumed in large quantities, their ranking revealed that they were eaten as encountered. Cladocera were not sampled effectively with our sampler and therefore not included in our analysis. If cladocerans would have been included, they would have had the highest preference, but other taxa would not have changed their relative positions.

Bluegill growth did not differ among plant densities. After $31 \mathrm{~d}$ bluegills averaged 63 $\mathrm{mm}$ (61-66 mm, 95\% confidence interval, CI) in the low plant density, $65 \mathrm{~mm}(61-70 \mathrm{~mm}, 95 \%$ $\mathrm{CI})$ in the medium plant density, and $65 \mathrm{~mm}(62-70 \mathrm{~mm}, 95 \% \mathrm{CI})$ in the high plant density. Therefore, bluegills grew at a rate about $16-18 \mathrm{~mm} / \mathrm{mo}$. 
Table 3. Number of invertebrates (median, 95\% confidence interval) in major taxa eaten per bluegill $(n=11-15$ bluegills per sample) in each plant stem density treatment and sampling date from Clark Lake, Ohio

\begin{tabular}{|c|c|c|c|c|c|c|c|c|c|c|c|c|}
\hline \multirow{4}{*}{$\begin{array}{l}\text { Invertebrate } \\
\text { taxon }\end{array}$} & \multicolumn{12}{|c|}{ Plant stem density treatment } \\
\hline & \multicolumn{4}{|l|}{ Low } & \multicolumn{4}{|c|}{ Medjum } & \multicolumn{4}{|l|}{ High } \\
\hline & \multicolumn{4}{|l|}{ Day } & \multicolumn{4}{|l|}{ Day } & \multicolumn{4}{|l|}{ Day } \\
\hline & 10 & 17 & 25 & 31 & 10 & 17 & 25 & 31 & 10 & 17 & 25 & 31 \\
\hline \multicolumn{13}{|l|}{ Chironomidae } \\
\hline larvae & $\begin{array}{l}30 \\
19,70\end{array}$ & $\begin{array}{l}30 \\
21,40\end{array}$ & $\begin{array}{l}56 \\
38,70\end{array}$ & $\begin{array}{l}52 \\
30,87\end{array}$ & $\begin{array}{l}13 \\
9,20\end{array}$ & $\begin{array}{l}19 \\
12,25\end{array}$ & $\begin{array}{l}28 \\
6,52\end{array}$ & $\begin{array}{l}32 \\
22,44\end{array}$ & $\begin{array}{l}23 \\
14,35\end{array}$ & $\begin{array}{l}26 \\
17,45\end{array}$ & $\begin{array}{l}30 \\
24,38\end{array}$ & ${ }^{12} 7,18$ \\
\hline pupae & $\begin{array}{l}8 \\
2,90\end{array}$ & $\begin{array}{l}23 \\
15,30\end{array}$ & $\begin{array}{l}24 \\
14,32\end{array}$ & $\begin{array}{l}50 \\
21,78\end{array}$ & $\begin{array}{l}2 \\
0,2\end{array}$ & $\begin{array}{l}2 \\
2,5\end{array}$ & $\begin{array}{l}1 \\
0,2\end{array}$ & $\begin{array}{l}27 \\
17,51\end{array}$ & $\frac{2}{2}, 4$ & $\begin{array}{l}4 \\
2,6\end{array}$ & $\begin{array}{l}<1 \\
0,2\end{array}$ & $\begin{array}{l}0 \\
0,0\end{array}$ \\
\hline Cladocera & $\begin{array}{l}4 \\
1,10\end{array}$ & $\begin{array}{l}0 \\
0,0\end{array}$ & $\begin{array}{l}0 \\
0,0\end{array}$ & $\begin{array}{l}0 \\
0,120\end{array}$ & $\begin{array}{l}14 \\
8,48\end{array}$ & $\begin{array}{l}0 \\
0,0\end{array}$ & $\begin{array}{l}13 \\
0,370\end{array}$ & $\begin{array}{l}330 \\
190,445\end{array}$ & $\begin{array}{l}27 \\
8,35\end{array}$ & $\begin{array}{l}0 \\
0,0\end{array}$ & $\begin{array}{l}0 \\
0,0\end{array}$ & $\begin{array}{l}162 \\
45,242\end{array}$ \\
\hline Physidae & $\begin{array}{l}0 \\
0,2\end{array}$ & $\begin{array}{l}2 \\
0,4\end{array}$ & $\begin{array}{l}0 \\
0,2\end{array}$ & $\begin{array}{l}3 \\
0,16\end{array}$ & $\begin{array}{l}0 \\
0,0\end{array}$ & $\begin{array}{l}1 \\
0,4\end{array}$ & $\begin{array}{l}5 \\
2,14\end{array}$ & $\begin{array}{l}4 \\
2,10\end{array}$ & $\begin{array}{l}0 \\
0,1\end{array}$ & $<1$ & $\begin{array}{l}12 \\
8,17\end{array}$ & $\begin{array}{l}16 \\
12,22\end{array}$ \\
\hline Baetidae & $\begin{array}{l}1 \\
0,2\end{array}$ & $\begin{array}{l}\mathrm{I} \\
0,2\end{array}$ & $\begin{array}{l}1 \\
0,2\end{array}$ & $\begin{array}{l}1 \\
0,2\end{array}$ & $\begin{array}{l}2 \\
1,2\end{array}$ & $\begin{array}{l}4 \\
2,6\end{array}$ & $\begin{array}{l}2 \\
0,4\end{array}$ & $\begin{array}{l}<1 \\
0,<1\end{array}$ & $\begin{array}{l}2 \\
2,7\end{array}$ & $\begin{array}{l}4 \\
2,6\end{array}$ & $\begin{array}{l}1 \\
0,3\end{array}$ & $\begin{array}{l}1 \\
0,2\end{array}$ \\
\hline Coenogrionidae & $\begin{array}{l}0 \\
0,0\end{array}$ & $\begin{array}{l}0 \\
0,0\end{array}$ & $\begin{array}{l}0 \\
0,<1\end{array}$ & $\begin{array}{l}0 \\
0,<1\end{array}$ & $\begin{array}{l}0 \\
0,1\end{array}$ & $\begin{array}{c}1 \\
<1,2\end{array}$ & $\begin{array}{l}2 \\
0,4\end{array}$ & $\begin{array}{l}0 \\
0,<1\end{array}$ & $<1,2$ & $\begin{array}{l}<1 \\
\quad 0,<1\end{array}$ & $<1,1,1$ & $\begin{array}{l}0 \\
0,<1\end{array}$ \\
\hline Other ${ }^{\mathrm{a}}$ & $\begin{array}{c}2 \\
<1,2\end{array}$ & $\begin{array}{l}4 \\
2,6\end{array}$ & 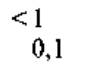 & $\begin{array}{l}2 \\
<1,2\end{array}$ & $\begin{array}{l}6 \\
4,8\end{array}$ & $\begin{array}{l}3 \\
2,4\end{array}$ & $\begin{array}{l}1 \\
0,3\end{array}$ & $\begin{array}{l}3 \\
2,5\end{array}$ & $\begin{array}{l}6 \\
4,12\end{array}$ & $\begin{array}{l}4 \\
2,6\end{array}$ & $\begin{array}{l}2 \\
1,2\end{array}$ & $\begin{array}{l}1 \\
0,2\end{array}$ \\
\hline
\end{tabular}

a Corixidae, Ceratopogonidae, Homoptera, and Leptoceridae were density, Other taxa eaten but with medians $=0$ for all dates and each eaten at rates of two or less per bluegill in each plant stem plant densities are not given

Immigration of bluegill from the main area of the lake did occur. Bluegill less than 40 $\mathrm{mm}(6 \%$ of total catch, $\mathrm{N}=449)$ and bluegill greater than $100 \mathrm{~mm}(12 \%$ of total catch) were considered immigrants and eliminated from the data analysis. The number of small and large immigrants did not change with plant density (Freidman's rank sum, $P=0.11$ ). As released bluegill were not marked, the remaining bluegill between 40 and $90 \mathrm{~mm}$ probably included some immigrants.

About one third of the bluegills initially stocked were recovered during the study $(34 \%$ in low, $34 \%$ in medium, and $28 \%$ in high). Some losses could be attributed to mortality and emigration, but entanglement of bluegill in vegetation probably resulted in additional losses during seining and rotenoning.

\section{Discussion}

We investigated the conflicting consequences to a predator of increasing vegetation density: an increase in prey density versus a decrease in capture rate. Crowder and Cooper (1982) predicted that an intermediate plant density would provide the optimal solution to this conflict. An intermediate density would provide a habitat with suitable numbers of prey and a reasonable capture rate and hence provide the maximal growth rate.

Our findings that invertebrate numbers increased with plant density agreed with those of most investigators (Gerking 1957; Gerrish and Bristow 1979; Wiley et al. 1984). In addition, invertebrate taxa and their relative proportion changed little with plant density. Most invertebrates were small enough to move through the enclosures; yet invertebrate numbers were not distributed equally in all sections. Predation by fish or habitat availability could account for changes in invertebrate numbers. Because fish density was constant and fish had similar diets 
across sections, predation intensity should be similar among sections. In open systems, the density of small fish could increase with increasing plant density via the resulting increase in refuge from their predators. An increasing fish density (and predation pressure) could cause macroinvertebrate density to asymptote with plant density. However, Flecker and Allan (1984) found that in stream substrate invertebrate abundance was directly related to spatial refugia rather than fish predation. In addition, Gilinsky (1984) found that even intense predation (10 bluegills $/ \mathrm{m}^{2}$ ) did not reduce macroinvertebrate mass associated with plants. Habitat availability, such as macrophyte density or substrate size, appears to be a primary factor regulating macroinvertebrate abundance; predator intensity may be secondary cause of variation.

Although invertebrate density increased with plant density in the field and capture rate of prey by bluegills in the laboratory declined with increasing plant density, bluegill diet and growth did not differ across the range of plant densities in the field. From our estimates of functions describing these conflicting effects of vegetation density, we can predict what vegetation density should provide the optimal foraging habitat for young-of-year bluegills. Marschall et al. (1989) found that prey-encounter rates for bluegill feeding in patches of artificial vegetation could adequately be described by an exponential distribution. We estimated the mean of this distribution, $\lambda$, using data from our laboratory experiments (eq. 1). From our field study, we can describe prey density, $\mathrm{n}$, as a function of vegetation density (eq. 2). Additionally, Marschall et al. (1989) showed that $\mathrm{T}_{\mathrm{n}}$, the time to first prey encounter in a patch with $\mathrm{n}$ prey, was distributed exponentially with mean of $\lambda / \mathrm{n}$. In our study, both $\lambda$ and $\mathrm{n}$ were functions of vegetation density, such that mean $T_{n}(v)=\lambda_{v} / n_{v}$. Solving for mean $T_{n}(v)$ from equations 1 and 2 yields

$$
\mathrm{T}_{\mathrm{n}}(\mathrm{v})=\left(5.7 \cdot \mathrm{e}^{0.0005 \mathrm{v}}\right) /\left(58 \cdot \mathrm{v}^{0.6}\right)
$$

Solving this function for the minimum $T_{n}(v)$ reveals that the absolute minimum occurs at a relatively high vegetation density of $1200 \mathrm{stems} / \mathrm{m}^{2}$.

We estimated $\lambda_{\mathrm{v}}$ in the laboratory using immobile prey distributed randomly on simple rope stems, so we may expect the actual capture rate in the field to be somewhat lower, given that live prey may choose more hidden locations on real plants. Our experiments comparing immobile prey to live prey show that ultimate foraging success was similar on the two, though we still might expect to see a capture rate reduction when we move to real plants from rope stems. This would translate into a reduction in the value of the parameter a in eq. (1), the function describing $\lambda_{\mathrm{v}}$. Because the minimum of $\mathrm{T}_{\mathrm{v}}$ depends only on the parameters in the exponents, and not on the parameter a, the location of the minimum is insensitive to this potential difference in absolute capture rates between laboratory and field.

Although the minimum $\mathrm{T}_{\mathrm{n}}(\mathrm{v})$ occurs at a very high vegetation density, a plot of this function (Fig. 4) shows that encounter rate changes little at vegetation densities above 100 stems $/ \mathrm{m}^{2}$; therefore, we expect little difference in bluegill growth above this vegetation density. Consequently, but unlike Crowder and Cooper (1982), bluegills did not grow optimally at a particular plant density. Our low plant density $\left(100-230 \mathrm{stems} / \mathrm{m}^{2}\right)$ overlapped with Crowder and Cooper's (1982) optimal plant density $\left(111 \mathrm{stems} / \mathrm{m}^{2}\right)$, but we did not reproduce their results. Bluegills in our study grew faster (about $17 \mathrm{~mm} / \mathrm{mo}$ ) in all plant densities than did those in Crowder and Cooper's (1982) (about $7 \mathrm{~mm} / \mathrm{mo}$, standard length adjusted to total length by a factor of 1.25), indicating that food was less limiting in our study. C. demersum was the primary plant species in Crowder and Cooper's (1982) study and is much more structurally complex than 
our P. nodosus (Fassett 1980). Coull and Wells (1983) found that only above a given threshold in structural complexity is predation reduced (blennies, Helcogramma medium, on meiofaune). Such a threshold was not reached in Clark Lake; hence we conclude that our natural range of plant densities provided accessible prey for all young-of-year bluegills.

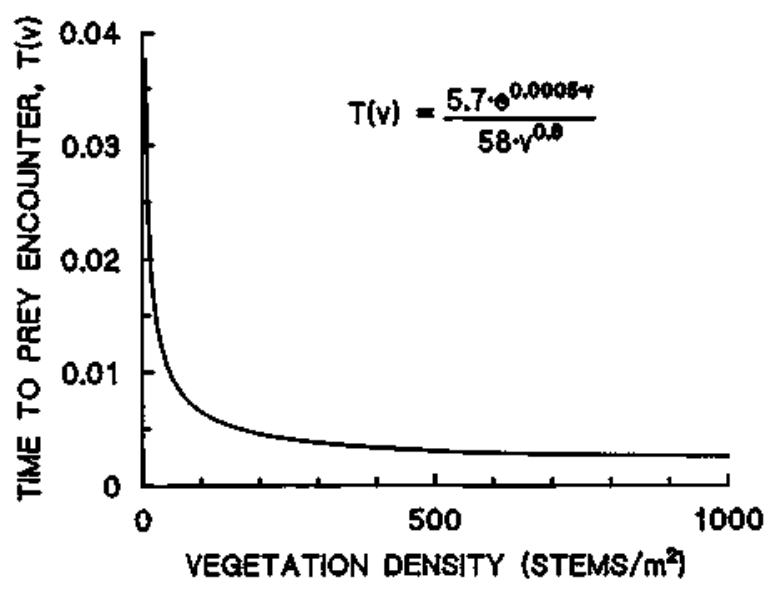

Fig. 4. Mean search time $\left(\mathrm{T}_{\mathrm{v}} ; \mathrm{min}\right)$ necessary for first prey capture in a $1-\mathrm{m}^{2}$ patch as a function of vegetation density $\left(\mathrm{v} ;\right.$ stems $/ \mathrm{m}^{2}$ ) as predicted by equation 3 (on figure and see text)

Changes in bluegill densities may alter intraspecific competition, thereby affecting growth (Murnyak et al. 1984). Yet, our bluegill densities (about $1 / \mathrm{m}^{2}$ ) were similar to those in studies by Crowder and Cooper $\left(1982 ; 1.3\right.$ bluegills $\left./ \mathrm{m}^{2}\right)$ and by Werner et al. $\left(1983 \mathrm{~b} ; 2.7 / \mathrm{m}^{2}\right)$. Given these similarities, bluegill density is unlikely to explain growth changes in response to vegetation density.

Because feeding behavior differs among predators, the ability to forage in different plant densities depends on predator type (Savino and Stein 1989a; Minello and Zimmerman 1983). Unlike largemouth bass and northern pike (Esox lucius) (Savino and Stein 1989a), bluegill do not ambush prey at high plant densities but actively search for prey. Capture efficiencies among predators also differ; red drum (Sciaenops ocellatus) and speckled trout (Cynoscion nebulosus) forage successfully on shrimp (Penaeus aztecuus) in vegetation but pinfish (Lagodon rhomboides) and Atlantic croaker (Micropogonias undulatus) do not (Minello and Zimmerman 1983). Largemouth bass could not capture bluegills in plant densities of $99-452 \mathrm{stems} / \mathrm{m}^{2}$ (Savino and Stein 1982, 1989a, 1989b); yet, bluegills in our study foraged successfully at 964 stems $/ \mathrm{m}^{2}$.

As Vinyard (1980) observed in bluegills and pumpkin-seeds (Lepomis gibbosus), bluegills in this study foraged similarly in all plant densities and preferred slow or immobile prey. Diet preferences of a predator (Octopus bimaculatus) in the field are a combination of the relative food preference for a prey species as determined in laboratory studies as well as by the relative abundance of that prey in the field (Ambrose 1984). Hence, bluegills preferred chironomid pupae, which were relatively few in numbers but vulnerable to bluegills as they move to the water surface prior to emergence (Oliver 1971), whereas cryptic, chironomid larvae, which were associated with vegetation but were relatively abundant, were eaten as encountered. Schramm and Jirka (1989) also found that adult bluegill generally preferred chironomids, but did 
not distinguish between the larvae and pupae in their analysis. Damselfly nymphs (Coenagrionidae) were avoided and in most cases not captured by bluegills in this field study. Our laboratory studies revealed that fewer damselflies were required to provide energy intake rates similar to chironomid larvae. However, energy intake rates also were more variable with damselflies, making them a riskier source of energy. Damselflies would move about the plants in the laboratory, actively avoiding predators. A similar mechanism in the field should reduce their encounter rate with predators and lower their predation rate over that expected based on relative abundance. Homoptera were abundant but limited to the water surface and eaten incidentally. Physidae, though abundant, were avoided by bluegills simply because bluegill, unlike their congener, pumpkinseed, do not possess molariform pharyngeal teeth necessary for crushing snails (Mittelbach 1984). Snails also were avoided by bluegills in the study by Schramm and Jirka (1989). From these studies, bluegills appear opportunistic, eating common prey and preferring those easily eaten and with low mobility.

If prey are accessible and common, then plant density should not influence bluegill growth (Bennett 1948). However, if preferred prey are not abundant, increasing plant density should increase their abundance and thereby enhance bluegill growth (Wiley et al. 1984). Alternatively, if preferred prey can effectively use vegetation as refuge, reducing such refuge should initially enhance bluegill growth (Cope et al. 1970). In our study all plant densities in Clark Lake enclosures provided accessible, abundant prey which, in turn, supported consistently high bluegill growth.

Given the predictions from Crowder and Cooper (1982) and the empirical results from other investigators (Cope et al. 1970; Crowder and Cooper 1982; Wiley 1984), we were surprised to document no change in bluegill growth with increasing vegetation density. Our interpretation is that once plants achieved a density of $>100 / \mathrm{m}^{2}$, macroinvertebrates became sufficiently abundant to easily meet the needs of young-of-year bluegill, as estimated from our laboratory foraging trials. To assess the role of refugia, such as vegetation, on foraging success and growth of predators, one must consider the intricate interaction between capture probabilities and prey densities. In Clark Lake, the quantitative interactions among macrophyte density, macroinvertebrate productivity, and bluegill foraging success led to constant bluegill growth across a wide range of macrophyte densities.

\section{Acknowledgments.}

We thank the many members of the Aquatic Ecology Laboratory of the Department of Zoology, The Ohio State University for their assistance. G. Eck, P. Hudson, and D. Wilcox comprehensively reviewed earlier drafts of this work. This study was funded by Dingell-Johnson project F-57-R administered through the Ohio Division of Wildlife. Elizabeth A. Marschall was supported by an Electric Power Research Institute Fellowship in Population Biology during the analysis, model development, and writing of this research. This manuscript is contribution 788 of the National Fisheries Research Center - Great Lakes, U.S. Fish and Wildlife Service, 1451 Green Road, Ann Arbor, Michigan 48105, USA.

\section{References}

Ambrose RF (1984) Food preferences, prey availability, and the diet of Octopus bimaculatus Verrill. J Exp Mar Biol Ecol 77:29-44

Anderson O (1984) The role of fish predation and spatial heterogeneity in determining benthic community structure. Ecology 65:455-468

Barnett BS, Schneider RW (1974) Fish populations in dense submersed plant communities. Hyacinth Control J $12: 12-14$

Bennett GW (1948) The bass-bluegill combination in a small artificial lake. Bull III Nat Hist Surv 24:377-412

Cook WL, Streams FA (1984) Fish predation on Notonecta (Hemiptera): relationship between prey risk and habitat 
utilization. Oecologia 64:177-183

Cope OB, Wood EM, Wallen GH (1970) Some chronic effects of 2,4-D on the bluegill (Lepomis macrochirus). Trans Am Fish Soc 99:1-12

Coull BC, Wells JBJ (1983) Refuges from fish predation: experiments with phytal meiofauna from the New Zealand rocky intertidal. Ecology 64:1599-1609

Crowder LB, Cooper WE (1982) Habitat structural complexity and the interaction between bluegills and their prey. Ecology 63:1802-1813

Cummins KW, Wuycheck JC (1971) Caloric equivalents for investigations in ecological energetics. Int Assoc Theor Appl Limnol Comm 18:1-158

Fassett NC (1980) A manual of aquatic plants. The University of Wisconsin Press, Madison, WI, USA

Fish PA, Savitz J (1983) Variations in home ranges of largemouth bass, yellow perch, bluegills, and pumpkinseeds in an Illinois Lake. Trans Am Fish Soc 112:147-153

Flecker AS, Allan JD (1984) The importance of predation, substrate and spatial refugia in determining lotic insect distributions. Oecologia 64:306-313

Fritz ES (1974) Total diet comparison in fishes by Spearman rank correlation coefficients. Copeia 1974:210-214

Gerking SD (1957) A method of sampling the littoral macrofauna and its application. Ecology 38:219-226

Gerrish N, Bristow JM (1979) Macroinvertebrate associations with aquatic macrophytes and artificial substrates. J Great Lakes Res 5:69-72

Gilinsky E (1984) The role of fish predation and spatial heterogeneity in determining benthic community structure. Ecology 65:455-468

Glass NR (1971) Computer analysis of predation energetics in the largemouth bass. In: Patten BC (ed) Systems analysis and simulation ecology, vol 1, Academic Press, New York, pp 325-361

Gotceitas V, Colgan P (1989) Predator foraging success and habitat complexity: quantitative test of the threshold hypothesis. Oecologia 80:158-166

Hollander M, Wolfe DA (1973) Nonparametric statistical methods. John Wiley and Sons, New York, NY, USA

Johnson DH (1980) The comparison of usage and availability measurements for evaluating resource partitioning. Ecology 61:65-71

Judd J, Taub S (1973) The effects of the ecological changes on Buckeye Lake, Ohio with emphasis on largemouth bass and aquatic vascular plants. Ohio Biol Surv Biol Notes No 6

Marschall EA, Chesson PL, Stein RA (1989) Foraging in a patchy environment: prey-encounter rate and residence time distributions. Anim Behav 37:444-454

Minello TJ, Zimmerman RJ (1983) Fish predation on juvenile brown shrimp, Penaeus aztecuus Ives: the effect of simulated Spartina structure on predation rates. J Exp Mar Biol Ecol 72:211-231

Mittelbach GG (1984) Predation and resource partitioning in two sunfishes (Centrarchidae). Ecology 65:499-513

Murnyak DF, Murnyak MO, Wolgast LJ (1984) Growth of stunted and nonstunted bluegill sunfish in ponds. Prog Fish-Cult 46:133-138

Oliver DR (1971) Life history of the Chironomidae. Annu Rev Entomol 16:211-230 Regier HA (1962) On the evolution of bass-bluegill stocking policies and management recommendations. Prog Fish-Cult 24:99-111

Savino JF, Stein RA (1982) Predator-prey interaction between largemouth bass and bluegills as influenced by simulated, submersed vegetation. Trans Am Fish Soch 111: 255-266

Savino JF, Stein RA (1989a) Behavioural interactions between fish predators and their prey: effects of plant density. Anim Behav 37:311-321

Savino JF, Stein RA (1989b) Behavior of fish predators and their prey: habitat choice between open water and dense vegetation. Env Biol Fish 24:287-293

Schramm HL, Jirka KJ (1989) Epiphytic macroinvertebrates as a food resource for bluegills in Florida lakes. Trans Am Fish Soc 118:416-426

Vinyard GL (1980) Differential prey vulnerability and predator selectivity: effects of evasive prey on bluegill (Lepomis macrochirus) and pumpkinseed (L. gibbosus) predation. Can J Fish Aquat Sci 37:2294-2299

Werner EE, Mittelbach GG, Hall DJ, Gilliam JF (1983a) Experimental tests of optimal habitat use in fish: the role of relative habitat profitability. Ecology 64:1525-1539

Werner EE, Gilliam JF, Hall DJ, Mittelbach GG (1983b) An experimental test of the effects of predation risk on habitat use in fish. Ecology 64:1540-1548

Wiley JJ, Gorden RW, Waite SW, Powless T (1984) The relationship between aquatic macrophytes and sport fish production in Illinois ponds: a simple model. N Am J Fish Man 4:111-119

Windell JT (1967) Rates of digestion in fishes. In: Gerking SD (ed) The biological basis of freshwater fish production. Blackwell Scientific Publications, Oxford, pp 151-173 